\title{
Diversification and Specialisation of Punjab in Growing Various Crops: A District Level Approach
}

\author{
Manpreet Kaur ${ }^{1 *}$ and Pavneet Kaur ${ }^{2}$ \\ ${ }^{1}$ Centre for Economic Studies, Central University of Punjab, Bathinda, India \\ ${ }^{2}$ Department of Economics, Akal University, Talwandi Sabo, Bathinda, India \\ *Corresponding author: manpreetkaur.mk1989@gmail.com
}

\begin{abstract}
The paper examines the nature and extent of crop diversification, crop specialization and inter-district diversity in cropping pattern in the most advanced agricultural state Punjab during the period of 2000-01 to 2014-15. The study has used the index of crop diversification, location quotient, crop versatility and district versatility index for analysis. The study has revealed that both wheat and rice crop is grown by all the districts, so none of the district was found to be very highly specialised or very less specialised than state. However, for cotton and maize, four districts acquired specialization. The district versatility results shows that Hoshiarpur is the more versatile district and Patiala is less versatile district in 2014-15. The insights from the paper suggests that the government should enhance region-specific diversification on the basis of district specialization along with infrastructure and assured marketing of new crops through contract farming and supermarkets procurement.
\end{abstract}

Keywords: Cropping pattern, crop diversification, crop specialisation, crop versatility index, district versatility index

In Punjab, although the share of agricultural and allied sector is declining in Gross State Domestic Product (GSDP) but still this sector absorbs a significant share of employment. Punjab, the grain bowl of India, has always remained ahead in achieving the target of food security since the advent of green revolution as despite having only 1.5 per cent of the geographical area; as it contributes around 42 per cent of wheat and 24 per cent of rice to the central pool (GoP, 2015). Consequently, area under wheat and rice has increased significantly. Above 80 per cent of the Gross Cropped Area (GCA) was under wheat and rice during 2014-15 (GoP, 2015). As a result, this has created the severe unbalanced situation for the cropping pattern of Punjab. The monoculture of wheat-rice crop rotation has originated some serious ecological as well as economic problems such as ground water depletion, decline in soil fertility, rise in water pollution due to over usage of chemicals, soil erosion, rising burden on state exchequer to provide free power supply to farm sector etc. Therefore, producing these traditional cereals is no longer viable for Punjab particularly, for combating these environmental and financial issues. As a result, there is dare need to focus on the cropping pattern of Punjab. The present cropping pattern of Punjab needs to be shifted from traditional food-grains towards high value crops to minimizes the adverse effects of the current system of crop specialization and monoculture for better resource use, reduction of risks and uncertainty and better soil conditions (Shergill, 2005; Acharya et al. 2011). Also, the demand for high value commodities such as fruits and vegetables is rising at a rapid rate and that of traditional food-grains such as rice, wheat etc. has declined considerably whereas in Punjab, the area under these crops is rising by every year and that of high value crops is very less. Hence, reshaping the cropping pattern of Punjab may solve the agrarian crisis of Punjab as the cropping pattern of any region or state plays a major role in determining the situation of 
agricultural sector of any state or region in terms of realizing higher output growth, higher farm income, employment generation, sustainability of natural resources and poverty alleviation (Kumar and Gupta, 2015). Besides, nature has also gifted Punjab with suitable agro-climatic conditions to grow various food as well as non-food crops. It is therefore, the present study based on district level analysis will be beneficial for policy makers to formulate specific policies by understanding cropping pattern for the coming years. The specific objectives of the study are (1) to study the changes in percentage share of area under different crops over a period of time; (2) to analyse the districtwise extent of crop diversification in Punjab; (3) to study the specialisation of various crops in various districts in Punjab; and (4) to examine the suitability of the different districts in various crops.

\section{Database and Methodology}

The present study is based on secondary data sources. District-wise data on area under different crops was compiled from various issues of Statistical Abstract of Punjab, Punjab at a Glance, Directorate of Horticulture, Punjab and indiastat.com etc. Mainly, 11 crops have been analysed in the present study, i.e. 3 rabi crops, namely, wheat, barley and total pulses (moong, masur and arhar), 5 kharif crops, namely, rice, cotton, maize, bajra and sugarcane and 3 others that includes fruits, vegetables and total oilseeds. The study covered the period from 2000-01 to 2014-15. At present, Punjab state has 22 districts, but due to non-availability of data for newly carved districts, the present study has combined these into 17 districts. Also, during 2000-01, there were 17 districts in Punjab. The data has been analysed for four different periods viz. 2000-01, 2005-06, 2010-11 and 2014-15. The study has examined the district-wise cropping pattern and specialisation/ concentration in growing various crops, by applying (a) Index of Crop Diversification (ICD) by Bhatia's method (b) Location Quotient (LQ) (c) Crop Versatility Index, and (d) District Versatility Index.

Bhatia's method for measuring crop diversification was used with the following method:

Index of Crop diversification $=$

Sum per cent of cropped area under X crops

Number of X crops
Where, $X$ crops are those crops which individually cover 10 per cent or more than 10 per cent of the cropped area or gross cropped area in each district. The index value calculated by this formula is inversely related to magnitude of crop diversification. It indicates that lower the index value higher is themagnitude of crop diversification and vice versa. If the index value is less than 20 , it shows very high diversification, 20.1 to 25.4 shows high diversification, 25.5 to 40.5 shows little diversification and greater than 40 indicates very little diversification (Bhatia, 1965).

It is widely accepted method to find the region-wise (district-wise in the present study) importance in various crops (Bhatia, 1965; Ardeshna and Shiyani, 2011; Ghosh, 2011; Ramphul, 2012; De and Bodosa, 2014). Hence, it is used for calculating the regional crop concentration.

$$
L Q_{i j}=\frac{A i j / A j}{A i / A}
$$

Where; $A i j=$ Area under crop ' $a$ ' in $j^{\text {th }}$ district

$A j=$ Gross Cropped Area (GCA) in $\mathrm{j}^{\text {th }}$ district

$A i=$ Area under crop ' $\mathrm{a}$ ' in the state

$A=\mathrm{GCA}$ of the state

Hence, it is the index for measuring the magnitude of the specialisation of a particular crop in a particular region. The value of LQ may equal to one, more than one or less than one. The value of LQ equal to unity shows the equal specialisation of a region/district vis-a-vis state in a particular crop. The value more than unity shows the more specialisation of a region in growing crop than state means the proportionate area under a specific crop in a particular district is more than the proportionate area under same crop in the state. However, the value less than one indicate the lesser specialisation of a region than state in a particular crop i.e. the proportion of a crop in a district to the GCA of a district is less than the proportion of the same crop to GCA in a state. Therefore, larger the value of $L Q$, higher will be the concentration of crop in a region and vice versa. Hence, it compares the relative situation of a crop in a region with that of the state level.

Crop Versatility Index is used to find out the coverage of a various crops in various regions or 
districts. A crop is said to be more versatile if it is grown in more number of regions. The versatility of crop is inversely related to the value of coefficient of variation $(\mathrm{CV})$ of a specific among various districts (Ramphul, 2012). The more the versatility of crop, lesser will be value of coefficient of variation and vice versa. The value of coefficient of variation $(\mathrm{CV})$ is calculated as follows;

$$
C V_{i}=\frac{\sigma A_{i}}{M_{i}} * 100
$$

Where, $C V_{i}=$ Coefficient of variation of share of area of $i^{\text {th }}$ crop

$\sigma A_{i}=$ Standard Deviation of the district-wise percentage share of area under crop ' $i$ '

$M_{i}=$ Average of district-wise percentage share of area under crop ' $i$ ' to GCA

Hence, higher value of CV will indicate the more region specific crop and lesser value will show more versatile crop.

As the crop versatility index indicates the performance of crops in the ability to grow more number of districts, similarly, the district versatility index reflects the suitability of various districts in growing more number of crops. A district is said to be more versatile if it is growing more number of crops with same percentage distribution of acreage of gross cropped area (Ramphul, 2012).

$$
C V_{j}=\frac{\sigma A_{j}}{M_{j}} * 100
$$

Where, $C V_{j}=C V$ of the percentage share of area under crops in district ' $j$ '

$\sigma A_{j}=$ Standard deviation of crop-wise percentage of area to total cropped area of $\mathrm{j}^{\text {th }}$ district

$M_{j}=$ Mean of the crop-wise percentage of area to total cropped area of $j^{\text {th }}$ district

The more the versatility of district, lesser will be value of coefficient of variation and vice versa.

\section{RESULTS AND DISCUSSION}

Punjab state has experienced the major changes in its cropping pattern since $1950-51$ as examined in Table 1. It is clear that proportionate area under rice experienced the surprising growth followed by wheat. This remarkable growth was principally due to the origin of Green Revolution occurred in late $60 s^{\prime}$. Hence, during this period, the area under wheat and rice rose from around 30 per cent and 5 per cent of GCA to 44 per cent and 37 per cent respectively during 2014-15. On the other hand, area under all other crops declined significantly except the marginal growth of area under fruits and vegetables. The proportionate area under total pulses declined from around 24 per cent during 1950-51 to just 0.1 per cent during 2014-15. Although, the growth of the area under fine cereals (wheat and rice) has fulfilled the target of food security of the nation as well as provided the remunerative returns to farmers, but at the same time, Punjab has caught into the net of many ecological problems and at present, is in serious agrarian crisis.

Table 2 shows the variations in the degree of crop diversification in Punjab amongst various districts. During 2000-01, only Hoshiarpur district showed the diversification with ICD value 24.68. However, the value of ICD for Ropar, Ferozpur, Bathinda, Mansa, S.B.S. Nagar and Jalandhar district lies between 25.5 to 40.5 and remaining districts have higher value than 40. Patiala and Fatehgarh Sahib has the least diversification with 43.39 and 43.82 ICD values, respectively. Punjab state with 37.94 ICD value lies in the low diversification category. In the fourth period (2014-15), in all the districts except Ropar the ICD value was recorded to increase. The value of ICD for Punjab increased to 40.5 in 201415. So, majority of the districts have experienced specialisation instead of diversification.

The perusal of Table 3 explains the extent of diversification in different districts of the state. During 2000-01 and 2014-15 time period, Faridkot, Kapurthala, Ludhiana, Gurdaspur, Amritsar, Sangrur, Moga, Patiala and Fatehgarh Sahib district did not experience the significant level of crop diversification and hence recorded a higher ICD values. Hoshiarpur and Ropar were only two districts that recorded a higher index of crop diversification during 2005-06. Even during this time period, two districts i.e. Kapurthala and Faridkot registered a little crop diversification as compared to very little crop diversification during other time periods. The reason behind it may be that during 2002, the government of Punjab introduced contract farming for hyola, maize, sunflower, barley and malting with the support of Punjab Agro Food- 
Table 1: Percentage share of area under various crops to Gross Cropped Area (GCA)

\begin{tabular}{cccccccccc}
\hline Crop & $\mathbf{1 9 5 0 - 5 1}$ & $\mathbf{1 9 6 0 - 6 1}$ & $\mathbf{1 9 7 0 - 7 1}$ & $\mathbf{1 9 8 0 - 8 1}$ & $\mathbf{1 9 9 0 - 9 1}$ & $\mathbf{2 0 0 0 - 0 1}$ & $\mathbf{2 0 0 5 - 0 6}$ & $\mathbf{2 0 1 0 - 1 1}$ & $\mathbf{2 0 1 4 - 1 5}$ \\
\hline Fruits & 0.8 & 0.6 & 0.6 & 0.4 & 0.9 & 0.4 & 0.6 & 0.9 & 1.0 \\
Vegetables & 1.2 & 1.2 & 0.9 & 1.1 & 0.7 & 1.4 & 1.3 & 1.3 & 1.6 \\
Rice & 2.9 & 4.8 & 6.9 & 17.5 & 26.8 & 33.0 & 33.7 & 35.9 & 36.6 \\
Bajra & 5.2 & 2.6 & 3.7 & 1 & 0.2 & 0.1 & 0.1 & 0.0 & 0.0 \\
Maize & 6.3 & 6.9 & 9.8 & 5.6 & 2.5 & 2.1 & 1.9 & 1.6 & 1.6 \\
Wheat & 27.3 & 29.6 & 40.5 & 41.6 & 43.6 & 42.9 & 44.1 & 44.5 & 44.4 \\
Barley & 2.4 & 1.4 & 1 & 0.9 & 0.5 & 0.4 & 0.2 & 0.2 & 0.1 \\
Total pulses & 23.8 & 19.1 & 7.3 & 5 & 1.9 & 0.7 & 0.4 & 0.3 & 0.1 \\
Total oilseeds & 3.3 & 3.9 & 5.2 & 3.7 & 1.4 & 1.1 & 1.0 & 0.7 & 0.6 \\
Sugarcane & 2.2 & 2.8 & 2.3 & 1 & 1.3 & 1.5 & 1.1 & 0.9 & 1.2 \\
Cotton & 5.4 & 9.4 & 7 & 9.6 & 9.3 & 5.9 & 7.1 & 6.1 \\
Others & 19.2 & 17.7 & 14.8 & 17.6 & 10.7 & 10.5 & 8.5 & 7.6 & 7.5 \\
\hline
\end{tabular}

Table 2: District-wise Index of Crop Diversification in Punjab by Bhatia's method

\begin{tabular}{|c|c|c|c|c|c|c|c|c|c|}
\hline \multirow[b]{2}{*}{ Districts } & \multicolumn{2}{|c|}{ 2000-01 } & \multicolumn{2}{|c|}{ 2005-06 } & \multicolumn{2}{|c|}{ 2010-11 } & \multicolumn{2}{|c|}{ 2014-15 } & \multirow[b]{2}{*}{ Name of the crops } \\
\hline & $\begin{array}{l}\text { No. of } \\
\text { crops }\end{array}$ & ICD & $\begin{array}{l}\text { No. of } \\
\text { crops }\end{array}$ & ICD & $\begin{array}{l}\text { No. of } \\
\text { crops }\end{array}$ & ICD & $\begin{array}{l}\text { No. of } \\
\text { crops }\end{array}$ & ICD & \\
\hline Ferozpur & 3 & 27.33 & 3 & 29.61 & 3 & 28.94 & 3 & 29.05 & Wheat, Rice and Cotton \\
\hline Hoshiarpur & 3 & 24.68 & 3 & 25.4 & 3 & 26.8 & 3 & 26.15 & Wheat, Rice and Maize \\
\hline $\begin{array}{l}\text { Sri Muktsar } \\
\quad \text { Sahib }\end{array}$ & 3 & 28.23 & 3 & 29.51 & 3 & 30.05 & 3 & 30.57 & Wheat, Rice and Cotton \\
\hline Bathinda & 3 & 29.00 & 3 & 29.34 & 3 & 30.4 & 3 & 30.64 & Wheat, Rice and Cotton \\
\hline Ropar & 3 & 25.87 & 3 & 22.81 & 3 & 27.14 & 3 & 25.77 & Wheat, Rice and Maize \\
\hline Mansa & 3 & 29.61 & 3 & 29.84 & 3 & 30.06 & 3 & 30.08 & Wheat, Rice and Cotton \\
\hline Faridkot & 2 & 40.69 & 3 & 30.04 & 2 & 42.91 & 2 & 44.05 & $\begin{array}{c}\text { Wheat and Rice (and Cotton } \\
\text { during 2005-06) }\end{array}$ \\
\hline Gurdaspur & 2 & 41.38 & 2 & 41.86 & 2 & 42.74 & 2 & 42.68 & Wheat and Rice \\
\hline Amritsar & 2 & 41.44 & 2 & 43.89 & 2 & 44.7 & 2 & 45.76 & Wheat and Rice \\
\hline Jalandhar & 2 & 36.62 & 2 & 37.68 & 2 & 40.78 & 2 & 39.86 & Wheat and Rice \\
\hline S.B.S. Nagar & 2 & 33.82 & 2 & 34.57 & 2 & 36.06 & 2 & 35.95 & Wheat and Rice \\
\hline Ludhiana & 2 & 41.06 & 2 & 42.25 & 2 & 42.9 & 2 & 43 & Wheat and Rice \\
\hline $\begin{array}{l}\text { Fatehgarh } \\
\text { Sahib }\end{array}$ & 2 & 43.82 & 2 & 44.24 & 2 & 44.65 & 2 & 44.27 & Wheat and Rice \\
\hline Moga & 2 & 42.25 & 2 & 46.33 & 2 & 45.56 & 2 & 46.08 & Wheat and Rice \\
\hline Sangrur & 2 & 41.61 & 2 & 43.5 & 2 & 44.21 & 2 & 43.85 & Wheat and Rice \\
\hline Kapurthala & 2 & 40.84 & 2 & 40.41 & 2 & 41.85 & 2 & 41.88 & Wheat and Rice \\
\hline Patiala & 2 & 43.39 & 2 & 46.15 & 2 & 44.9 & 2 & 45.42 & Wheat and Rice \\
\hline Punjab & 2 & 37.94 & 2 & 38.89 & 2 & 40.19 & 2 & 40.5 & Wheat and Rice \\
\hline
\end{tabular}

grains Corporation for the diversification of state agriculture.

Table 4 illustrates the LQ of rabi crops (wheat, barley and total pulses) for the time periods of 2000-01, 2005-06, 2010-11 and 2014-15. In case of wheat crop, none of the district was found to be very highly specialised or very less specialised than state. Therefore, in all the 17 districts, the value of
LQ was found to near about one i.e. slightly more than and less than one for all the time periods. Therefore, wheat crop was found to be grown in all the districts. In case of barley crop, the specialisation was found to be highest in Sri Muktsar Sahib and Bathinda districts $(\mathrm{LQ}=2.18$ for both the districts) during 2000-01 but over a period of time, the specialisation of these two districts started 
Table 3: District-wise extent of crop diversification during various time periods

\begin{tabular}{|c|c|c|c|}
\hline Year & High & Little & Very Little \\
\hline 2000-01 & Hoshiarpur & $\begin{array}{l}\text { Ropar, Ferozpur, Bathinda, Mansa, S.B.S. Nagar, } \\
\text { Jalandhar and Punjab }\end{array}$ & $\begin{array}{l}\text { Faridkot, Kapurthala, Ludhiana, Gurdaspur, } \\
\text { Amritsar, Sangrur, Moga, Patiala, Fatehgarh Sahib }\end{array}$ \\
\hline 2010-11 & - & $\begin{array}{l}\text { Hoshiarpur, Ropar, Ferozpur, Sri Muktsar Sahib, } \\
\text { Mansa, Bathinda, S.B.S. Nagar, Punjab }\end{array}$ & $\begin{array}{l}\text { Jalandhar, Kapurthala, Gurdaspur, Ludhiana, } \\
\text { Faridkot, Sangrur, Fatehgarh Sahib, Amritsar, } \\
\text { Patiala, Moga }\end{array}$ \\
\hline 2014-15 & - & $\begin{array}{l}\text { Ropar, Hoshiarpur, Ferozpur, Mansa, Sri Muktsar } \\
\text { Sahib, Bathinda, S.B.S. Nagar, Jalandhar, Punjab }\end{array}$ & $\begin{array}{l}\text { Kapurthala, Gurdaspur, Ludhiana, Sangrur, } \\
\text { Faridkot, Fatehgarh Sahib, Patiala, Amritsar, Moga }\end{array}$ \\
\hline
\end{tabular}

Table 4: District-wise Location Quotient of Rabi crops

\begin{tabular}{|c|c|c|c|c|c|c|c|c|c|c|c|c|}
\hline \multirow{2}{*}{ District } & \multicolumn{4}{|c|}{ Wheat } & \multicolumn{4}{|c|}{ Barley } & \multicolumn{4}{|c|}{ Total Pulses } \\
\hline & 2000-01 & 2005-06 & 2010-11 & 2014-15 & 2000-01 & 2005-06 & 2010-11 & 2014-15 & 2000-01 & 2005-06 & 2010-11 & 2014-15 \\
\hline Ferozpur & 0.97 & 1.02 & 1 & 0.99 & 1.68 & 1.93 & 2.22 & 1.61 & 1.10 & 1.09 & 1.33 & 1.04 \\
\hline $\begin{array}{l}\text { Sri Muktsar } \\
\text { Sahib }\end{array}$ & 1.02 & 1.02 & 0.99 & 1.05 & 2.18 & 1.86 & 1.51 & 1.61 & 0.93 & 0.87 & 0.54 & 0.32 \\
\hline Bathinda & 1.01 & 0.99 & 1.02 & 1.03 & 2.18 & 1.49 & 2.36 & 1.29 & 0.74 & 0.85 & 0.71 & 0.64 \\
\hline Mansa & 1.03 & 1.02 & 1.04 & 1.02 & 1.90 & 2.29 & 1.8 & 1.95 & 0.56 & 0.61 & 0.65 & 0.20 \\
\hline Faridkot & 1.05 & 1.04 & 1.03 & 1.04 & 0.97 & 0.00 & 0 & 0.00 & 2.16 & 0.98 & 1.24 & 0.29 \\
\hline Gurdaspur & 1.02 & 1.03 & 1.01 & 1.02 & 0.00 & 0.00 & 0 & 0.00 & 0.84 & 1.33 & 1.96 & 2.28 \\
\hline Amritsar & 1.02 & 1.02 & 1.03 & 1.03 & 0.00 & 0.00 & 0 & 0.00 & 1.17 & 1.10 & 1.11 & 2.01 \\
\hline Jalandhar & 0.94 & 0.91 & 0.93 & 0.90 & 0.00 & 0.00 & 0 & 0.00 & 0.36 & 0.97 & 0.77 & 1.03 \\
\hline Moga & 1.02 & 1.07 & 1.04 & 1.03 & 0.61 & 1.13 & 0 & 0.00 & 2.00 & 1.43 & 1.44 & 0.75 \\
\hline Sangrur & 1.02 & 1.02 & 1.02 & 1.01 & 1.92 & 2.36 & 2.24 & 2.43 & 1.22 & 1.35 & 1.03 & 1.05 \\
\hline Kapurthala & 0.99 & 0.93 & 0.9 & 0.91 & 0.00 & 0.00 & 0 & 0.00 & 0.17 & 0.10 & 0 & 0.00 \\
\hline Patiala & 1.02 & 1.09 & 1.02 & 1.02 & 0.69 & 0.74 & 1.22 & 1.34 & 0.55 & 0.30 & 0 & 0.00 \\
\hline
\end{tabular}

decline and remained only 1.61 and 1.29 for Sri Muktsar Sahib and Bathinda districts respectively during 2014-15. At the same time, the speciality of Fatehgarh Sahib district in barley crop firstly fell down from with a LQ value of 1.12 during 2000-01 to zero during 2005-06 and 2010-11 and after that went up to 3.74 implying that the district covers the proportionate area under barley crop 3.74 times more than the proportionate area in the entire state. Similarly, Faridkot district was found to be highly specialised in case of total pulses during 2000-01 while in 2014-15, the value of LQ declined to 0.29.

Similarly, Table 5 explains the district-wise specialisation of kharif crops with the help of LQ method. Rice is the dominant kharif crop and was found to be grown in all the districts and due to this, no district was found to be very highly specialised in rice. However, Hoshiarpur, Bathinda, Ropar, Mansa, Ferozpur, Sri Muktsar Sahib and S.B.S. Nagar districts were found to be comparatively less specialised than state. In case of cotton crop, except Faridkot, all the South-west belt of Punjab comprising Ferozpur, Bathinda, Sri Muktsar Sahib and Mansa have been doing their best and due to this reason, the South-west belt of Punjab is also known as cotton belt. However, during 2014-15, with the fluctuations in LQ value, the performance of Bathinda and Mansa districts has grown up and that of the Sri Muktsar Sahib districts has come down. In Sri Muktsar Sahib district, the 
Table 5: District-wise Location Quotient of Kharif crops

\begin{tabular}{|c|c|c|c|c|c|c|c|c|c|c|c|c|c|c|c|c|c|c|c|c|}
\hline \multirow{3}{*}{ Districts } & \multicolumn{4}{|c|}{ Rice } & \multicolumn{4}{|c|}{ Cotton } & \multicolumn{4}{|c|}{ Maize } & \multicolumn{4}{|c|}{ Sugarcane } & \multicolumn{4}{|c|}{ Bajra } \\
\hline & & 005 & 01 & & & 2005 & 2010 & 201 & & $5-$ & 201 & 001 & - & 20 & 2010- & 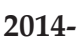 & 000 & $05-$ & 201 & $01 x^{-1}$ \\
\hline & 01 & 06 & 11 & 15 & 01 & 06 & 11 & 15 & 01 & 06 & 11 & 15 & 01 & 06 & 11 & 15 & 01 & 06 & 11 & 15 \\
\hline Fer & 0.84 & 0.82 & 0.81 & 0.87 & 1 & 2.30 & 2.13 & 2.08 & 0.00 & 0.00 & 0 & 0.00 & 0.59 & 0.11 & 0.13 & 0.19 & 0.00 & 0.00 & .96 & 0 \\
\hline Hoshiarpur & 0.52 & 0.51 & 0.57 & 0.54 & 0.00 & 0.00 & 0 & 0.00 & 8.67 & 9.83 & 10.27 & 10.36 & 3.01 & 5.51 & 5.05 & 5.18 & 0.00 & 0.00 & 0 & 0 \\
\hline $\begin{array}{c}\text { Sri } \\
\text { Muktsar } \\
\text { Sahib }\end{array}$ & 3 & 0.51 & & & & 3.71 & & & & 0.00 & 0 & & & 1 & 26 & 0.00 & 00 & .00 & 0 & 0 \\
\hline Bathinda & 0.53 & 0.51 & 0.54 & 0.58 & 4.38 & 3.84 & 4.31 & 4.69 & 0.09 & 0.00 & 0 & 0.11 & 0.00 & 0.00 & 0 & 0.00 & 2.82 & 2.84 & 0 & 0 \\
\hline Ropar & 0.71 & 0.68 & 0.76 & 0.57 & 0.00 & 0.00 & 0 & 0.00 & 6.41 & 5.81 & 6.52 & 6.85 & 3.15 & 1.52 & 1.34 & 1.41 & 0.00 & 0.00 & 0 & 0 \\
\hline Mansa & 0.70 & 0.57 & 0.59 & 0.61 & 3.60 & 3.55 & 3.92 & 4.29 & 0.00 & 0.00 & 0 & 0.00 & 0.20 & 0.00 & 0 & 0.00 & 4.33 & 4.35 & 7.17 & 0 \\
\hline Faridkot & 1.11 & 1.01 & 11 & 1.15 & 0.95 & 1.45 & 0.96 & 0.75 & 0.00 & 0.00 & 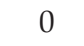 & 0.00 & 0.53 & 0.37 & 0 & 0.00 & 0.00 & 0.00 & 0 & 0 \\
\hline Gurdaspur & 1.18 & 1.13 & 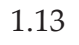 & 1.09 & 0.00 & 0.00 & 0 & 0.00 & 1.25 & 1.39 & 1.34 & 1.12 & 2.42 & 3.95 & 4.7 & 4.66 & 0.00 & 3.16 & 0 & 0 \\
\hline Amritsar & 1.18 & 1.27 & 1.22 & 1.19 & 0.04 & 0.02 & 0.02 & 0.00 & 0.29 & 0.19 & 0.15 & 0.08 & 0.85 & 0.68 & 0.41 & 0.41 & 0.00 & 0.00 & 0 & 0 \\
\hline Jalandhar & 1.00 & 1.05 & 1.12 & 1.09 & 0.00 & 0.00 & 0 & 0.00 & 1.87 & 1.50 & 1.35 & 1.20 & 2.36 & 2.42 & 2.49 & 2.21 & 0.00 & 0.00 & 0 & 0 \\
\hline $\begin{array}{l}\text { S.B.S. } \\
\text { Nagar }\end{array}$ & 0.83 & 0.83 & 0.88 & 0.84 & 0.00 & 0.00 & 0 & 0.00 & 4.73 & 5.16 & 4.67 & 3.39 & 4.55 & 3.75 & 3.08 & 2.73 & 0.00 & 0.00 & 0 & 0 \\
\hline Ludhiana & 1.20 & 1.24 & 1.2 & 1.18 & 0.03 & 0.02 & 0.03 & 0.00 & 0.33 & 0.18 & 0.2 & 0.32 & 0.78 & 0.31 & 0.38 & 0.43 & 0.00 & 0.00 & 0 & 0 \\
\hline $\begin{array}{c}\text { Fatehgarh } \\
\text { Sahib }\end{array}$ & 1.32 & 1.32 & 1.22 & 1.22 & 0.00 & 0.00 & 0 & 0.00 & 0.25 & 0.00 & 0 & 0.33 & 1.39 & 0.98 & 1.2 & 1.31 & 0.00 & 0.00 & 0 & 0 \\
\hline Moga & 1.23 & 1.35 & 1.25 & 1.26 & 0.34 & 0.27 & 0.13 & 0.05 & 0.00 & 0.00 & 0 & 0.00 & 0.20 & 0.00 & 0 & 0.00 & 4.05 & 0.00 & 0 & 0 \\
\hline Sangrur & 1.20 & 1.24 & 1.19 & 1.17 & 0.39 & 0.35 & 0.39 & 0.45 & 0.05 & 0.06 & 0 & 0.14 & 0.20 & 0.11 & 0.26 & 0.38 & 3.52 & 3.59 & 2.98 & 0 \\
\hline Kapurthala & 1.19 & 1.18 & 1.22 & 1.18 & 0.00 & 0.00 & 0 & 0.00 & 0.73 & 0.59 & 0.45 & 0.69 & 1.25 & 1.38 & 1.25 & 1.24 & 0.00 & 0.00 & 0 & 0 \\
\hline Patiala & 1.30 & 1.32 & 1.24 & 1.25 & 0.03 & 0.03 & 0.03 & 0.00 & 0.48 & 0.38 & 0.23 & 0.35 & 0.33 & 0.34 & 0.42 & 0.47 & 0.00 & 0.00 & 0 & 0 \\
\hline
\end{tabular}

decline in the speciality in cotton crop is mainly due to the rise of the problem of waterlogging (rise of water level above critical level as well as rise of salinity in water). Over the entire period of time, the performance of maize crop has been remaining highest in Hoshiarpur and has been also increased from 8.67 during 2000-01 to 10.36 during 2014-15 indicates that this district occupies proportionate area under maize 10.36 times more than proportionate area under maize in the state. Besides Hoshiarpur district, Ropar and S.B.S. Nagar have also been doing their best in maize crop with 6.85 LQ value in Ropar and 3.39 in S.B.S. Nagar during 2014-15. Apart from maize crop, Hoshiarpur district also has highest specialisation in sugarcane crop among all the districts holding 5.05 LQ value during 2014-15 increased from 3.01 during 2000-01 followed by Gurdaspur district with a LQ value of 2.42 during 2000-01 and rose to 4.66 during 201415. Whereas during the same period of time, the specialisation of Ropar and S.B.S. Nagar districts in sugarcane cropdeclined from 3.15 and 3.39 to 1.41 and 3.08 respectively. During 2014-15, the area under bajra crop declined almost to zero and therefore, during the period of 2000-01 to 2010-11, except Mansa, Sangrur and Ferozpur, in all other districts, the value of LQ was declined to zero. During 2000-01 to 2010-11, the concentration of Mansa district rose from 4.33 to 7.17 and Ferozpur district also performed well by uplifting its value from zero to 2.96. Value of LQ in Sangrur district fell down from 3.52 during 2000-01 to 2.98 during 2010-11.

Table 6 describes the district-wise specialisation of non-traditional crops such as fruits, vegetables and oilseeds with the help of LQ method. In case of fruits specialisation was found in Hoshiarpur district with 3.12 LQ value followed by Ferozpur district with 2.15 LQ value during 2000-01 while in 2014-15, Ferozpur district recorded highest specialisation with 3.40 LQ value and Hoshiarpur district shifted to the 
Table 6: District-wise Location Quotient of Fruits, Vegetables and Total Oilseeds

\begin{tabular}{|c|c|c|c|c|c|c|c|c|c|c|c|c|}
\hline \multirow{2}{*}{ District } & \multicolumn{4}{|c|}{ Fruits } & \multicolumn{4}{|c|}{ Vegetables } & \multicolumn{4}{|c|}{ Total Oilseeds } \\
\hline & $2000-01$ & 2005-06 & 2010-11 & 2014-15 & $2000-01$ & 2005-06 & 2010-11 & 2014-15 & $2000-01$ & 2005-06 & 2010-11 & 2014-15 \\
\hline Ferozpur & 2.15 & 2.46 & 3.06 & 3.40 & 0.30 & 0.38 & 0.45 & 0.46 & 1.48 & 1.66 & 0.87 & 1.06 \\
\hline $\begin{array}{l}\text { Sri Muktsar } \\
\text { Sahib }\end{array}$ & 1.62 & 1.56 & 1.68 & 1.57 & 0.47 & 0.33 & 0.32 & 0.17 & 0.90 & 0.60 & 0.39 & 0.46 \\
\hline Bathinda & 0.91 & 0.95 & 0.85 & 0.84 & 0.76 & 1.22 & 0.98 & 0.66 & 1.05 & 1.21 & 0.56 & 0.62 \\
\hline Mansa & 0.19 & 0.21 & 0.31 & 0.28 & 0.14 & 0.22 & 0.25 & 0.21 & 0.93 & 1.09 & 0.85 & 0.93 \\
\hline Faridkot & 0.57 & 0.67 & 0.62 & 0.56 & 0.38 & 0.26 & 0.27 & 0.43 & 0.71 & 0.30 & 0 & 0.00 \\
\hline Gurdaspur & 1.28 & 1.08 & 0.98 & 0.96 & 0.47 & 0.24 & 0.35 & 0.35 & 1.26 & 0.91 & 1.12 & 1.19 \\
\hline Amritsar & 0.74 & 0.62 & 0.52 & 0.46 & 0.98 & 0.55 & 0.88 & 0.94 & 1.44 & 0.82 & 0.88 & 0.88 \\
\hline Jalandhar & 0.39 & 0.40 & 0.44 & 0.41 & 3.05 & 4.11 & 1.05 & 2.52 & 1.39 & 2.09 & 2.87 & 1.07 \\
\hline Moga & 0.06 & 0.13 & 0.15 & 0.13 & 1.36 & 0.00 & 1.16 & 1.01 & 0.57 & 0.21 & 0.37 & 0.45 \\
\hline Sangrur & 0.57 & 0.53 & 0.28 & 0.25 & 0.39 & 0.49 & 0.38 & 0.41 & 0.41 & 0.28 & 0.32 & 0.58 \\
\hline Kapurthala & 0.18 & 0.23 & 0.21 & 0.11 & 2.62 & 3.82 & 4.17 & 3.87 & 0.74 & 1.52 & 1.41 & 0.95 \\
\hline Patiala & 0.90 & 0.80 & 0.52 & 0.47 & 1.21 & 1.02 & 1.49 & 1.16 & 0.37 & 0.33 & 0.52 & 0.64 \\
\hline
\end{tabular}

Table 7: District-wise specialisation in different crops during various years (Crops in descending order as per the magnitude of its location quotient (LQ $>1)$

\begin{tabular}{|c|c|c|c|c|}
\hline District & 2000-01 & 2005-06 & 2010-11 & 2014-15 \\
\hline Ferozpur & $\begin{array}{l}\text { Fruits, Cotton, Barley, Total } \\
\text { oilseeds and Total pulses }\end{array}$ & $\begin{array}{l}\text { Fruits, Cotton, Barley, Total } \\
\text { oilseeds, Total pulses and } \\
\text { Wheat }\end{array}$ & $\begin{array}{l}\text { Fruits, Bajra, Barley, Cotton and } \\
\text { Total pulses }\end{array}$ & $\begin{array}{l}\text { Fruits, Cotton, Barley, Total } \\
\text { oilseeds and Total pulses }\end{array}$ \\
\hline Bathinda & $\begin{array}{l}\text { Cotton, Bajra, Barley, Total } \\
\text { oilseeds and Wheat }\end{array}$ & $\begin{array}{l}\text { Cotton, Bajra, Barley, } \\
\text { Vegetables and Total oilseeds }\end{array}$ & Cotton, Barley and Wheat & Cotton, Barley and Wheat \\
\hline Ropar & $\begin{array}{l}\text { Maize, Sugarcane, Fruits, } \\
\text { Total pulses and Total } \\
\text { oilseeds }\end{array}$ & $\begin{array}{l}\text { Maize, Fruits, Sugarcane, Total } \\
\text { pulses and Total oilseeds }\end{array}$ & $\begin{array}{l}\text { Maize, Total oilseeds, Fruits, } \\
\text { Sugarcane and Total pulses }\end{array}$ & $\begin{array}{l}\text { Maize, Total Pulses, Total } \\
\text { oilseeds, Fruits, Sugarcane, } \\
\text { Vegetables and Wheat }\end{array}$ \\
\hline Gurdaspur & $\begin{array}{l}\text { Sugarcane, Fruits, Total } \\
\text { oilseeds, Maize, Rice and } \\
\text { Wheat }\end{array}$ & $\begin{array}{l}\text { Sugarcane, Bajra, Maize, Total } \\
\text { pulses, Rice, Fruits and Wheat }\end{array}$ & $\begin{array}{l}\text { Sugarcane, Total pulses, Maize, } \\
\text { Rice, Total oilseeds and Wheat }\end{array}$ & $\begin{array}{l}\text { Sugarcane, Total pulses, Total } \\
\text { oilseeds, Maize, Rice and } \\
\text { Wheat }\end{array}$ \\
\hline Amritsar & $\begin{array}{l}\text { Total oilseeds, Rice, Total } \\
\text { pulses and Wheat }\end{array}$ & Rice, Total pulses and Wheat & Rice, Total pulses and Wheat & Total pulses, Rice and Wheat \\
\hline Jalandhar & $\begin{array}{l}\text { Vegetables, Sugarcane, } \\
\text { Maize and Total oilseeds }\end{array}$ & $\begin{array}{l}\text { Vegetables, Sugarcane, Total } \\
\text { oilseeds, Maize and Rice }\end{array}$ & $\begin{array}{l}\text { Total oilseeds, Sugarcane, } \\
\text { Maize, Rice and Vegetables }\end{array}$ & $\begin{array}{l}\text { Vegetables, Sugarcane, Maize, } \\
\text { Rice, Total oilseeds and Total } \\
\text { pulses }\end{array}$ \\
\hline S.B.S. Nagar & $\begin{array}{l}\text { Maize, Sugarcane, Total } \\
\text { oilseeds and Vegetables }\end{array}$ & $\begin{array}{l}\text { Maize, Sugarcane, Total } \\
\text { oilseeds and Vegetables }\end{array}$ & $\begin{array}{l}\text { Maize, Sugarcane, Total } \\
\text { oilseeds and Vegetables }\end{array}$ & $\begin{array}{l}\text { Maize, Sugarcane, Vegetables } \\
\text { and Total oilseeds }\end{array}$ \\
\hline
\end{tabular}




\begin{tabular}{|c|c|c|c|c|}
\hline Ludhiana & $\begin{array}{l}\text { Total pulses, Vegetables, } \\
\text { Rice and Barley }\end{array}$ & $\begin{array}{l}\text { Total pulses, Barley, Rice and } \\
\text { Vegetables }\end{array}$ & $\begin{array}{l}\text { Vegetables, Total pulses, Rice } \\
\text { and Barley }\end{array}$ & $\begin{array}{l}\text { Vegetables, Total pulses, } \\
\text { Barley and Rice }\end{array}$ \\
\hline Fatehgarh Sahib & $\begin{array}{l}\text { Sugarcane, Rice, Barley } \\
\text { and Wheat }\end{array}$ & Rice and Vegetables & $\begin{array}{l}\text { Vegetables, Rice, Sugarcane } \\
\text { and Wheat }\end{array}$ & $\begin{array}{l}\text { Barley, Total oilseeds, } \\
\text { Vegetables, Sugarcane and } \\
\text { Rice }\end{array}$ \\
\hline Moga & $\begin{array}{l}\text { Bajra, Total pulses, } \\
\text { Vegetables, Rice and } \\
\text { Wheat }\end{array}$ & $\begin{array}{l}\text { Total pulses, Rice, Barley and } \\
\text { Wheat }\end{array}$ & $\begin{array}{l}\text { Total pulses, Rice, Vegetables } \\
\text { and wheat }\end{array}$ & Rice, Wheat and Vegetables \\
\hline Sangrur & $\begin{array}{l}\text { Bajra, Barley, Total pulses, } \\
\text { Rice and Wheat }\end{array}$ & $\begin{array}{l}\text { Bajra, Barley, Total pulses, Rice } \\
\text { and Wheat }\end{array}$ & $\begin{array}{l}\text { Bajra, Barley, Rice, Total pulses } \\
\text { and Wheat }\end{array}$ & Barley, Rice, Pulses and Wheat \\
\hline Kapurthala & $\begin{array}{l}\text { Vegetables, Sugarcane and } \\
\text { Rice }\end{array}$ & $\begin{array}{l}\text { Vegetables, Total oilseeds, } \\
\text { Sugarcane and Rice }\end{array}$ & $\begin{array}{l}\text { Vegetables, Total oilseeds, } \\
\text { Sugarcane and Rice }\end{array}$ & $\begin{array}{l}\text { Vegetables, Sugarcane and } \\
\text { Rice }\end{array}$ \\
\hline Patiala & $\begin{array}{l}\text { Rice, Vegetables and } \\
\text { Wheat }\end{array}$ & Rice, Wheat and Vegetables & $\begin{array}{l}\text { Vegetables, Rice, Barley and } \\
\text { Wheat }\end{array}$ & $\begin{array}{l}\text { Barley, Rice, Vegetables and } \\
\text { Wheat }\end{array}$ \\
\hline
\end{tabular}

Table 8: Crop Versatility Index during various time periods

\begin{tabular}{|c|c|c|c|c|}
\hline Crops & 2000-01 & 2005-06 & 2010-11 & 2014-15 \\
\hline Fruits & 104.08 & 111.02 & 137.03 & 152 \\
\hline Vegetables & 77.53 & 96.98 & 76.3 & 74.75 \\
\hline Rice & 63.23 & 65.85 & 60.68 & 60.44 \\
\hline Wheat & 51.37 & 51.5 & 50.72 & 50.5 \\
\hline Maize & 170.07 & 191.37 & 202.21 & 199.69 \\
\hline Bajra & 199.95 & 199.95 & 222.76 & 0 \\
\hline Barley & 123.44 & 137.52 & 148.34 & 133.24 \\
\hline Total pulses & 74.87 & 76.52 & 88.45 & 108.38 \\
\hline Total oilseeds & 74.31 & 79.06 & 80.79 & 65.77 \\
\hline Sugarcane & 81.06 & 135.9 & 143.7 & 143.05 \\
\hline Cotton & 169.97 & 166.07 & 171.29 & 177.37 \\
\hline
\end{tabular}

second rank with 2.55 LQ value. During 2000-01, the performance of Jalandhar was best in vegetables with 3.03 LQ value followed by Hoshiarpur district with 2.88 LQ value and Kapurthala with 2.62 LQ value. But over the period of time, the performance of Kapurthala district improved for vegetables with 3.87 LQ value, however, its performance declined in case of Jalandhar and Hoshiarpur districts with 2.52 and $0.90 \mathrm{LQ}$ values, respectively. Hoshiarpur district also found to be specialised in oilseeds cultivation among all the districts holding 3.51 LQ value during 2014-15 increased from 2.05 during 2000-01 followed by Ropar district with a LQ value of 1.23 during 2000-01 that increased to 2.96 during 2014-15.

On the basis of preceding analysis the districts were classified according to specialization in different crops during four periods between years 2000-01 to 2014-15 and reported in Table 7. Out of the total 17 districts in the state, only four acquire specialization in cotton and maize each in all the four periods. Further, seven districts obtained specialization in sugarcane and barley each in 2014-15.

Table 8 contains the versatility index for major crops grown in Punjab. It is observed that wheat (51.37) is more versatile crop followed by rice (63.23), pulses and oilseeds (around 74 each) and vegetables (77.53) during 2000-01. Bajra (199.95) and maize (170.07) are less versatile crops and grown in the specific regions of the state. Bajra is more region specific during 2010-11 reflected by its versatility index value (222.76). Further, during 2014-15, wheat (50.5), rice (60.44) and oilseeds (65.77) are versatile crops grown in wider areas while, maize (199.69) and cotton (177.37) are more region- specific crops grown in the specific areas of the state. The analysis shows that wheat,rice, oilseeds and vegetables are more versatile crops as compared to maize, cotton, fruits and sugarcane in state.

The district versatility results for different time periods are presented in Table 9. The analysis of table reveals that Hoshiarpur district (151.48) is 
Table 9: District Versatility Index during different time periods

\begin{tabular}{ccccc}
\hline District & $\mathbf{2 0 0 0 - 0 1}$ & $\mathbf{2 0 0 5 - 0 6}$ & $\mathbf{2 0 1 0 - 1 1}$ & $\mathbf{2 0 1 4 - 1 5}$ \\
\hline Ferozpur & 177.48 & 172.08 & 119.40 & 175.15 \\
Hoshiarpur & 154.68 & 144.53 & 154.88 & 151.48 \\
Muktsar & 173.56 & 171.67 & 171.04 & 182.17 \\
Bathinda & 174.85 & 168.94 & 175.22 & 176.34 \\
Ropar & 167.38 & 148.69 & 165.61 & 163.28 \\
Mansa & 177.42 & 172.22 & 177.2 & 173.81 \\
Faridkot & 195.34 & 184.39 & 196.75 & 202.78 \\
Gurdaspur & 195.72 & 190.59 & 194.41 & 195.01 \\
Amritsar & 204.22 & 201.44 & 205.41 & 206.44 \\
Jalandhar & 182.29 & 169.18 & 184.95 & 181.02 \\
S.B.S. Nagar & 169.33 & 158.93 & 163.42 & 164.88 \\
Ludhiana & 203.97 & 193.84 & 196.16 & 197.36 \\
Fatehgarh Sahib & 207.38 & 203.15 & 205.03 & 203.00 \\
Moga & 202.79 & 213.67 & 209.69 & 213.22 \\
Sangrur & 205.19 & 199.02 & 202.8 & 201.53 \\
Kapurthala & 198.73 & 183.09 & 190.51 & 191.07 \\
Patiala & 208.30 & 212.66 & 206.12 & 209.44 \\
\hline
\end{tabular}

more versatile amongst all the districts which imply that more number of crops grown in the district during entire period under analysis. However, Patiala district (208.30) is less versatile district implying less number of crops are grown in district during 2000-01 while in 2014-15, Moga is less versatile district with 213.22 district versatility value and Patiala became the second less versatile district with 209.44 versatility value. The versatility index for districts viz. Moga, Patiala, Muktsar, Bathinda, Amritsar and Faridkot showed the increasing trend that implies that these regions are moving towards specialization. Thus, the results suggest that in these districts, there is essential need for crop diversification.

\section{CONCLUSION}

The performance of all the districts of Punjab growing various crops has been assessed throughICD, LQ, Crop Versatility Index and District Versatility Index over the period of 2000-01 to 2014-15. The study reveals that the area under two crops i.e. wheat-rice grew from 30 per cent during 1950-51 to above 80 per cent during 201415. The reasons behind increasing preference of wheat-rice monoculture among Punjab farmers are assured irrigation facilities and regulated market along Minimum Support Price by the Government of India. Hoshiarpur and Ropar are only two districts that recorded a higher index of crop diversification during 2005-06. In case of barley crop, the specialisation was found to be highest in Sri Muktsar Sahib and Bathinda districts during 2000-01 with value of LQ to be more than two but over a period of time in 2014-15, the specialisation of these two districts started decline and the value LQ remained only 1.61 and 1.29, respectively. Hoshiarpur district was also found to be thehighest specialised in oilseeds cultivation among all the districts holding 3.51 LQ value during 2014-15. Further, during 2014-15, wheat (50.5), rice (60.44) and oilseeds (65.77) were found to be the versatile crops grown in wider areas while, maize (199.69) and cotton (177.37) were more region- specific crops grown in the specific areas of the state. The district versatility results revealed that Hoshiarpur (151.48) is the more versatile district while Moga (213.22) is the less versatile district during 2014-15. Thus, there has been a move towards specialization rather than crop diversification in the state. Further, the government's strategy of shifting area out of wheat-rice does not seem to be working effectively in the state. The Punjab government should enhance region-specific diversification on basis of district specialization along with infrastructure such as processing firms, cold stores etc. and assured 
marketing of new crops through contract farming and supermarkets procurement.

\section{REFERENCES}

Acharya, S.P., Basavaraja, H., Kunnal, L.B., Mahajanashetti, S.B. and Bhat, A.S.R. 2011. Crop diversification in Karnataka: An economic analysis. Agric Econ Res Review, 24: 351-357.

Ardeshna, N.J. and Shiyani, R.L. 2011. District-wise performance and suitability of growing crops in Gujarat, Agric situation in India, 68(4): 173-181.

Bhatia, S.S. 1965. Patterns of crop concentration and diversification in India. Econ Geogr., 41(1): 39-56.

De, U.K. and Bodosa, K. 2014. Crop diversification in Assam and use of modern inputs under changing climatic conditions. Climatology and Weather Forecasting, 2(2): 1-14.
Ghosh, B.K. 2011. Essence of crop diversification: A study of West Bengal agriculture. Asian J. of Agric Res., 5(1): 28-44.

Government of Punjab. Statistical Abstract of Punjab, Economic and Statistical Organization, Chandigarh, Punjab. 2015.

Kumar, S. and Gupta, S. 2015. Crop diversification towards high-value crops in India: A state level empirical analysis. Agric Econ Res Review, 28(2): 339-350.

Ramphul. 2012. Performance and suitability of growing crops in Haryana: District-level analysis. Agric situation in India, 69(1): 27-32.

Shergill, H.S. 2005. Wheat and Paddy cultivation and the question of optimal cropping pattern in for Punjab. J. of Punjab Studies, 12(2): 239-250. 